FIÁTH Attila - MEGYES Judit - TÓTH Andrea

\title{
A HAZAI POSTAPIACI LIBERALIZÁCIÓRA VALÓ FELKÉSZÜLÉS KÉRDÉSKÖREI
}

A jelenlegi uniós szabályozás célkitúzései között szerepel a postapiac liberalizációja, a verseny elôsegítése, az egyetemes szolgáltatók mellett más piaci szereplók megjelenésének ösztönzése. A 2008-as III. postai irányelv értelmében a teljes piacnyitásban hazánkat 2012. december 31-ig derogáció illeti meg. E felkészülési idôszakban az illetékes hatóságoknak a piac szabályozásában jelentôs lépéseket kell tenniük. Az egyik legjelentôsebb változtatás a közszolgáltatások kapcsán központi problémaként említhetố egyetemes szolgáltatásokat érinti. E szolgáltatások vonatkozásában a hatályba lépó új irányelv a korábbiakhoz mérten szigorúbb, mindenki számára elérhetố, meghatározott minőségú szolgáltatás nyújtására kötelezi az egyetemes szolgáltatókat, mely számukra jelentôs többletterhet (többletköltséget) róhat. Jelen értekezés rövid áttekintést nyújt az európai uniós postapiaci szabályozás fontosabb aspektusairól, jellemzi a fóbb, többletteher számítására kialakított modelleket, valamint bemutatja a hazai postapiac liberalizációjáig terjedő felkészülési idôszak központi kérdésköreit.

Kulcsszavak: posta, liberalizáció, nettó költség

Az I. postai irányelv (97/67/EK) az egyetemes szolgáltatási kör indokoltságát a következővel magyarázza: „...meghatározott minôségü minimális szolgáltatási kört, amelyet elérhetö áron minden felhasználó érdekében, minden tagállamban nyújtani kell” (97/67/EK (11) bekezdése).

Tekintve, hogy az európai uniós előírások alapján az egyetemes szolgáltatási kötelezettség heti öt alkalommal történő, minden felhasználó számára elérhető szolgáltatás nyújtását jelenti, szükséges volt e kötelezettségból adódó lehetséges többletteher finanszírozásának megoldása. A teljes piacnyitásig ezt a célt az ún. fenntartott szolgáltatások szolgálják, illetve szolgálták. A fenntartott szolgáltatások az egyetemes szolgáltatások egy részét képezik, azonban ezeket kizárólag az egyetemes szolgáltató nyújthatja, melynek célja, hogy e szolgáltatásokból befolyó bevétellel finanszírozza az esetleges egyéb egyetemes szolgáltatások nyújtása miatt elszenvedett veszteségeit.

A II. postai irányelv (2002/39/EK) egyik legfontosabb célja, hogy a piacliberalizációra való fokozatos felkészülést elôsegítve szúkítse a fenntartott szolgáltatási kört. Fontos hangsúlyozni, hogy az irányelvek a fenntartott szolgáltatások legszélesebb körét határoz-

Az egyetemes szolgáltatások és azon belül a fenntartott szolgáltatási kör 
zák meg (vagyis a fenntartható szolgáltatásokat), és az egyes tagállamok maguk dönthetnek, hogy a piaci sajátosságok figyelembevételével milyen széles körben határozzák meg a fenntartott szolgáltatásokat. ${ }^{1}$

A teljes piacnyitást követôen (Magyarországon 2013. január 1-jétốl) az egyetemes szolgáltató számára fenntartott szolgáltatási jogok megszúnnek, ezáltal a továbbiakban bármely piaci szereplő múködtetheti e szolgáltatásokat. Ebból kifolyólag a 2008-as, III. postai irányelv (2008/6/EK) a piacnyitás vonatkozásában a következô feladatok elvégzését rendeli el a tagországok számára:

1. Az egyetemes szolgáltatási kötelezettségekból (universal service obligation, USO) adódó többletteher számszerúsítése.

2. Az esetleges többletteher finanszírozási mechanizmusának kialakítása.

A következókben a releváns európai uniós iránymutatásokat ismertetjük, emellett mind a többletteher számszerúsítésénél, mind a finanszírozási mechanizmusnál bemutatjuk a lehetséges alkalmazandó modelleket.

\section{Az egyetemes szolgáltatási kötelezettségekból adódó többletteher számszerúsítése}

A III. postai irányelv rendelkezik a fenntartott szolgáltatások megszüntetését követően meghatározandó többletteher, vagyis a nettó költség számításának alapelveiról. Ennek értelmében a nettó költség két állapot közötti eltérést mutatja: az adott szolgáltató egyetemes szolgáltatási kötelezettségekkel és e kötelezettségek nélküli állapotának különbségét. Az iránymutatás értelmében a nettó költség számítása során figyelembe kell venni az egyetemes szolgáltatás nyújtása tekintetében keletkező előnyöket, beleértve a nem tárgyi hasznokat is.

A nettó költség kalkulációjának a következő okokból felmerült költségeken kell alapulnia:

1. A meghatározott szolgáltatások olyan elemei, amelyeket csak veszteséggel vagy a szokásos kereskedelmi normáktól eltéró költségfeltételek mellett lehet nyújtani.

E csoportba tartozhatnak a szociális alapon nyújtandó szolgáltatások költségei, mint például a vakok és gyengénlátók számára nyújtandó szolgáltatások.

2. Konkrét szolgáltatást felhasználók vagy felhasználók csoportjai, akiket - figyelembe véve a szolgáltatás nyújtásának költségét, a keletkezó bevételt és a tagállam által esetlegesen elöírt egységes árakat - csak veszteségesen vagy a szo- kásos kereskedelmi normáktól eltéró költségfeltételek mellett lehet kiszolgálni.

E fogyasztók lehetnek például egyes falvak lakói, melyek vonatkozásában veszteséges a heti öt alkalommal való kézbesítés.

A nettó költség számításánál megállapítható, hogy a III. irányelv kizárólag alapelveket fogalmaz meg, ezzel jelentős mozgásteret adva a szabályozó hatóságoknak és az egyetemes szolgáltatóknak.

Tekintve, hogy az elkövetkezô hároméves felkészülési idôszakban hazánkban szükséges lesz az egyetemes szolgáltatási kötelezettségekból adódó nettóköltség-számítási módszertan kidolgozása, e tanulmány egymástól eltérô alapokon nyugvó modell ismertetését túzte ki célul. A következókben a Net Avoidable Cost, az Entry Pricing, valamint a Profitability Cost módszerek számítási metódusait, azok előnyeit, valamint hátrányait mutatjuk be.

\section{A nettó elkerülhetố költség (Net Avoidable Cost-NAC) módszer}

A NAC-módszer célja, hogy azon elkerülhető költségtömeget számszerúsíti, mely nem keletkezne, ha az adott szolgáltatónak nem lennének egyetemes szolgáltatási kötelezettségei. Ez a módszer a veszteséges piaci területek költségét hivatott számszerúsíteni.

A nettó elkerülhető költség módszere a következô lépésekból áll (Ballebye Olesen et al., 2008):

(1) A postapiac szegmentálása

Az elsô lépés keretében a vizsgálandó piac specifikumait figyelembe véve eltérô szegmenseket alakítanak ki. Általában három dimenzió alapján lehet meghatározni a piaci területeket: a termék (szolgáltatás), a földrajzi és a szolgáltatás gyakoriságának dimenziója segítségével. Így például egy szegmens az egy kg alatti postacsomag hétvégi kézbesítése a vidéki területeken.

(2) A veszteséges szegmensek feltérképezése

A profit egyszerúen a bevételek és a költségek különbsége, azonban kizárólag az elkerülhetó költségek figyelembevétele az elfogadható. Az elkerülhető költségek kizárólagos figyelembevételének oka, hogy a nettó költség az a költségtömeg, mely a vállalat múködése során nem jelentkezne (vagyis elkerülhető lenne), amennyiben nem lenne egyetemes szolgáltatási kötelezettsége. A közös költségek számításokba való beépítése korlátozottan lehetséges. Ennek oka, hogy a közös költség nem elkerülhető, ha egy kézbesítő a veszteséges $1 \mathrm{~kg}$ alatti csomagokat már nem kézbesíti vidékre, a nyereséges 1-2 kg közöttieket azonban kiszállítja. 
(3) A veszteségek összege az egyetemes szolgáltatások nyújtása miatt elszenvedett nettó költség.

A NAC-módszerrel számított nettó költség illusztrációját tartalmazza az 1 . táblázat.

\section{1. táblázat}

A nettó elkerülhető költség módszer számítási metódusa

\begin{tabular}{|c|c|c|}
\hline NAC & Profit & USO költség \\
\hline 1. szegmens & -100 & 100 \\
\hline 2. szegmens & 200 & 0 \\
\hline 3. szegmens & 50 & 0 \\
\hline Összesen & 150 & 100 \\
\hline
\end{tabular}

Forrás: Ballebye Olesen et al., 2008:98 alapján

A NAC-módszert számos kritika érte.

A modell azzal a feltételezéssel él, hogy ha egy üzletágat megszüntetünk, annak semmilyen következménye nem lesz a többi üzletágra. Ezáltal figyelmen kívül hagyja, hogy a fogyasztók egy kis részénél veszteséges termék, más esetben egy másik termék fogyasztását generálja. Erre jó példa a hétvégi újság kézbesítése, melynek hiányában lehet, hogy a fogyasztó egy versenytárs szolgáltatását venné igénybe, és nem elégedne meg a munkanapokon történó kézbesítéssel. A modell e feltételezésének lehetséges hatását szemlélteti a 2. táblázat.

2. táblázat

A nettó elkerülhetố költség módszer hibás feltételezésének hatása a megmaradó üzletágra

\begin{tabular}{|c|c|c|c|c|}
\hline $\begin{array}{c}\text { Módositott } \\
\text { NAC }\end{array}$ & Profit & $\begin{array}{r}\text { Prof } \\
\text { szegme }\end{array}$ & $\begin{array}{l}\text { fit az } 1 \text {. } \\
\text { nens nélkül }\end{array}$ & USO költség \\
\hline 1. szegmens & -100 & 1. szegmens & 0 & 0 \\
\hline 2. szegmens & 200 & $\underset{\mathrm{a} 2 \text {. szegmensre }}{\stackrel{\text { hiányának hatása }}{P}}$ & 50 & 0 \\
\hline 3. szegmens & 50 & & 50 & 0 \\
\hline Összesen & 150 & & 100 & 0 \\
\hline
\end{tabular}

Forrás: Ballebye Olesen et al., 2008:100 alapján

A módszer másik hátránya, hogy a nettó költség értéke függ a piaci szegmensek kialakításától, ezáltal jelentôsen befolyásolható a végeredmény. $\mathrm{Az}$ aggregáltság fokának növekedésével - vagyis több termék, nagyobb terület, szélesebb időskála meghatározásával - egyre kevesebb veszteséges szegmens azonosítható. Ennek oka, hogy magasabb aggregáltsági szinten az egyes termékek egymást keresztfinanszírozzák, ezáltal az egyetemes szolgáltatási kötelezettség terhe egyre kevesebbnek túnik (3. táblázat).
A NAC-modell nem veszi figyelembe a keresleti hatásokat, mivel a kézbesítés helyét és egyéb paramétereit veszi alapul, pedig a kereslet a feladónál keletkezik.

A módszer a jelenlegi piaci körülményekkel számol, nem veszi figyelembe a liberalizáció okozta változásokat, például az új belépốk hatását az árak alakulására.

Mindemellett a NAC-módszer figyelmen kívül hagyja a brand-re vonatkozó fogyasztói attitúdöket, mellyel együtt nem számol az egyetemes szolgáltatási kötelezettségekból adódó hasznokkal. ${ }^{1}$

Legjelentősebb előnye a NAC-módszernek a könynyen számszerúsíthetố nettó költség, mivel a számításhoz szükséges információk viszonylag könnyen előállíthatók.

\section{Entry Pricing módszer}

Az Entry Pricing modell lényege, hogy a liberalizáció miatti költségeket számszerúsíti. Az Entry Pricing úgy tekint az egyetemes szolgáltató veszteségére, hogy az a liberalizáció következménye.

E módszer a monopol- és a versenypiaci helyzetben lévố szolgáltató profitját számszerúsíti, ezáltal az egyetemes szolgáltatási kötelezettségek többletterhe helyett a liberalizáció többletterhét hivatott számszerúsíteni.

Az Entry Pricing modell a következő lépésekból áll (Ballebye Olesen et al., 2008):

\section{(1) A piaci szegmensek kialakítása}

Ez a lépés megegyezik a NAC-módszernél ismertetett első lépéssel.

(2) Azon szegmensek feltérképezése, melyekre várható új szolgáltató belépése

Egy új belépó a jelenleg monopolpiaci helyzetben lévố egyetemes szolgáltató (fizetôképes) keresletének egy részét elveheti.

\section{(3) A profit csökkenésének számszerüsitése}

Az utolsó lépésben a lehetséges új belépő hatásait szükséges számszerúsíteni. A veszteség megállapítá-

\section{3. táblázat}

A nettó elkerülhetố költség módszer végeredményének befolyásolási lehetôsége: a szegmensek meghatározásának hatása

\begin{tabular}{|c|c|c|c|c|}
\hline $\begin{array}{l}\text { Módosított } \\
\text { NAC }\end{array}$ & Aggregált profit & $\begin{array}{l}\text { Aggregált USO } \\
\text { költség }\end{array}$ & $\begin{array}{l}\text { Aggregált profit - } \\
\text { módosult }\end{array}$ & $\begin{array}{l}\text { Aggregált USO } \\
\text { költség - módosult }\end{array}$ \\
\hline 1. szegmens & -100 & 100 & -100 & 100 \\
\hline 2. szegmens & 200 & 0 & & \\
\hline 2. szegmens A & & & & 0 \\
\hline 2. szegmens B & & & & $\rightarrow 50$ \\
\hline 3. szegmens & 50 & 0 & 50 & :öltsség \\
\hline Összesen & 150 & 100 & 150 & 150 \\
\hline
\end{tabular}

Forrás: Ballebye Olesen et al., 2008:101 alapján 
sához meg kell becsülni, hogy mekkora volumencsökkenéssel járhat az új belépó megjelenése. A volumen csökkenésével együtt járhat költségmegtakarítás is, melyet ugyancsak szükséges figyelembe venni.

A modell utolsó lépéseként az egyes szegmenseken kimutatott veszteségeket (profitcsökkenés) aggregálják.

E módszer nem felel meg teljes mértékben az EU III. irányelvében megfogalmazott alapelveknek, tekintve, hogy az Entry Pricing modell a liberalizáció terhét számszerüsíti, nem pedig az egyetemes szolgáltatás költségét. A versenypiaci és a monopolhelyzetben lévő vállalati állapot közötti bevételkiesést próbálja számszerúsíteni.

Az Entry Pricing modell esetében is befolyással bír a végeredményre a piaci szegmensek kialakítása.

Egy másik fontos hátránya a módszernek, hogy figyelmen kívül hagyja a nem nyereséges szegmenseket, pedig ott is következhet be bevételcsökkenés.

Mindemellett az Entry Pricing előnye, hogy különbözô szcenáriókat lehet értékelni a verseny intenzitásától és a piac szabályozottságától függően.

\section{A Profitability Cost modell}

E módszertan a következő feltevésen alapszik: az egyetemes szolgáltatások nyújtása során felmerülő nettó költség megegyezik az egyetemes szolgáltatások nyújtása során elért versenypiaci profit és a kötelezettségek nélküli versenypiaci profit különbségével.

A Profitability Cost módszer lépései a következôk (Ballebye Olesen et al., 2008):

(1) Azon szolgáltatások azonosítása, melyeket a szolgáltató az egyetemes szolgáltatási kötelezettségek hiányában is nyújtani fog
(2) Az inkrementális (elkerülhetô) költségek számszerúsítése

Az elkerülhető költségeket a Profitability Cost modell az egyetemes szolgáltatási kötelezettségek megléte mellett nyújtott szolgáltatások költségének és az üzleti alapon nyújtott szolgáltatások költségének különbségeként határozta meg.

\section{(3) Az inkrementális bevétel számszerüsítése}

$\mathrm{Az}$ inkrementális költségek számszerúsítéséhez hasonlóan számítandó. Az inkrementális bevételek három részből tevődnek össze: közvetlen bevételi hatás, árhatás és keresleti hatás.

A közvetlen bevételi hatás azon szolgáltatások bevétele, melyeket kizárólag a kötelezettségek megléte mellett nyújt a szolgáltató. Az inkrementális bevétel árhatása azon bevételkiesést tartalmazza, mely a kötelezettségek nélküli árváltozásból ered. Például amennyiben egyes szolgáltatások ára mesterségesen alacsonyan van tartva, annak érdekében, hogy a szegényebb fogyasztók is hozzáférjenek, valószínúleg a kötelezettségek hiányában e szolgáltatás ára emelkedni fog. És végül a keresleti hatás azon bevétel változását jelenti, mely amiatt jelentkezik, mert egyes fogyasztók kereslete a továbbra is nyújtandó termékek iránt megváltozhat, ha egyes, általuk igénybe vett szolgáltatások megszúnnek. Erre példa egy vállalati ügyfél, mely több földrajzi területre küld levelet. Amennyiben ezek közül egy terület (ritkán lakott, vidéki terület) vonatkozásában a szolgáltató megszünteti szolgáltatásait, nagy valószínúséggel a fogyasztó egy olyan versenytárstól veszi majd igénybe a szolgáltatásokat, mely minden, általa igényelt területet lefed.

Az inkrementális bevétel számszerúsíthetőségét a 2. ábra részletezi.

2. ábra

\section{Az inkrementális bevétel számszerúsítési módszertana}

$$
\mathrm{R}^{\mathrm{USO}}-\mathrm{R}^{\mathrm{USO} \text { nélkül }}=\underbrace{\left(\mathrm{Q}_{\mathrm{x}}^{\mathrm{USO}}\right) \mathrm{PUSO}^{\mathrm{USO}}}_{\text {Közvetlen bevételi hatás }}+\underbrace{\left(\mathrm{P}^{\mathrm{USO}}-\mathrm{PUSO}^{\mathrm{USO} \text { nélkül}}\right) \mathrm{Qy} \mathrm{USO}}_{\text {Árhatás }}+\underbrace{\left(\mathrm{Qy} \mathrm{ySO}^{\mathrm{USO}} \mathrm{Qy} \text { USO nélkül}\right) \mathrm{P}^{\mathrm{USO}} \text { nélkül }}_{\text {Keresleti hatás }}
$$

\section{$\mathrm{Q}_{\mathrm{x}}=$ kizárólag az egyetemes szolgáltatási kötelezettségek megléte mellett nyújtott (veszteséges) szolgá ltatá sok menny isége \\ $\mathrm{Q}_{\mathrm{Y}}=\mathrm{a}$ kötelezettségek hiányában is nyújtandó, nyereséges szolgálta tások mennyisége}

Az egyetemes szolgáltatónak kötelezettségek nélkül, kizárólag gazdasági alapon is megéri egyes szolgáltatások nyújtása a versenypiacon. E szolgáltatások hatását pedig nem szabad figyelembe venni a nettó költség számítása során.
Ez a módszer figyelembe veszi a liberalizáció okozta lehetséges változásokat, valamint az egyetemes szolgáltatási kötelezettségból adódó hasznokra is fókuszál.

Szükséges megjegyezni, hogy a Profitability Cost módszer egy elméleti módszer, melynek gyakorlatba 
való átültetése nehézségekbe ütközhet. A módszer alkalmazásához széles körú piaci ismeretek szükségesek. Feltételezésekkel kell élni a piacnyitás utáni időszakot illetôen, mely bizonytalanná teszi, hogy az eredmény valóban tükrözi-e az egyetemes szolgáltatási kötelezettségek által a vállalatra rótt teher mértékét.

A következókben a Profitability Cost módszertan egy gyakorlatba átültetett változatát mutatjuk be, melyet Dániában fejlesztettek ki. A gyakorlati példánál a választás azért a Profitability Cost módszerre esett, mert e modell a leginkább szubjektív, és kritikái között leginkább a nehéz gyakorlati alkalmazás állt.

\section{Commercial Approach -}

a Profitability Cost módszertan gyakorlati megközelítése Dánia példáján keresztüil

(Ballebye Olesen et al., 2008)

A Profitability Cost módszertan gyakorlati megközelítése a kereskedelmi szemléletú módszertan. A módszer azokból a lépésekból áll, mint a már ismertetett Profitability Cost módszer, ezáltal a modell fókuszában a következő kérdés áll:

Milyen változás következne be az üzleti stratégiájában az egyetemes szolgáltatónak, ha nem lennének kötelezettségei? (vagyis ha már nem lenne egyetemes szolgáltató)

Dániában a stratégiaváltást hét dimenzió elemzésén keresztül vizsgálták: földrajzi, szolgáltatási, termék,

\section{A heti 6 helyett 5 alkalommal történó kézbesítés általi költségcsökkentési lehetôségek a Dán Posta tekintetében}

\begin{tabular}{|c|c|c|}
\hline Dimenziók & Követelmények & $\begin{array}{l}\text { Lehetséges } \\
\text { költségcsökkentési } \\
\text { változtatások }\end{array}$ \\
\hline Földrajzi & $\begin{array}{c}\text { Egész ország területén történő } \\
\text { szolgáltatás }\end{array}$ & $\begin{array}{l}\text { Egyes költségesebb } \\
\text { területek ellátásának } \\
\text { megszüntetése }\end{array}$ \\
\hline Szolgáltatás & Heti 6x-i kézbesités & Heti 5x-i kézbesítés \\
\hline Termék & Ingyenes szolgáltatások a vakoknak & $\begin{array}{l}\text { Ezen szolgáltatások } \\
\text { bizonyos dijhoz kötése }\end{array}$ \\
\hline Árak & Egységes országos árak & Ármegkülönböztetés \\
\hline Postaláda & Országos hálózat & $\begin{array}{l}\text { Postaládák számának } \\
\text { csökkentése }\end{array}$ \\
\hline Posta & Országos hálózat & $\begin{array}{l}\text { Posták számának } \\
\text { csökkentése }\end{array}$ \\
\hline Egyéb & $\begin{array}{l}\text { Számviteli követelmények, különleges } \\
\text { jogok a bélyegek tekintetében stb. }\end{array}$ & $\begin{array}{l}\text { Egyéb követelmények } \\
\text { megszünése. }\end{array}$ \\
\hline
\end{tabular}

Forrás: Ballebye Olesen et al., 2008:12 alapján árak, postaláda, posta, egyéb. Ezen dimenziók elemzése során a 4. táblázatban ismertetett lehetséges költséghatékonysági tényezóket definiálták a dán piacra.

A dán piac vonatkozásában megállapították, hogy a leginkább szignifikáns követelmény, melynek hiányában a legtöbb költséget lehetne megtakarítani az az országos, valamint a heti hatszori kézbesítés.

$\mathrm{Az}$ egész ország lefedésének költsége jelentősen függ az adott ország adottságaitól.

A Dán Postára (Post Danmark) készített számítások alapján 40 millió dán koronát (közel 1,5 milliárd Ft-ot) lehetne megtakarítani, amennyiben a Dán Posta a népesség mintegy $1 \%$-át, a peremvidékeken lakókat nem szolgálná ki. Azonban figyelembe kell venni ennek a változásnak a Dán Posta megmaradó szolgáltatásainál támasztott keresleti hatásait is. Tekintve azt, hogy a peremvidékek kiszolgálása hiányában a Dán Posta a legnagyobb ügyfeleitől, a bankoktól, közszolgáltatóktól eshetne el, az elemzés során megállapították, hogy egy ilyen jellegú változtatás gazdasági alapon nem valószínú, mivel a költségcsökkentés mellett jelentős bevételkieséssel járna.

A Dán Posta másik jelentôs teherrel járó kötelezettsége a heti hatszori kézbesítés.

Ebben az esetben a hatodik napon dolgozó kézbesítók bérét lenne képes megtakarítani a Dán Posta, azonban ennek a változásnak két hatása lenne a további múködésére:

\section{4. táblázat}

(1) Hétfótól péntekig bizonyos szinten megnövekedne a kézbesítendố termékek száma, ezáltal a kézbesítési költség is.

(2) Bizonyos mértékben csökkenne a bevétel, melynek oka, hogy azon fogyasztók egy része, akik mind a 6 napon igénybe vették a szolgáltatást, ezután valamely versenytárstól veszik majd igénybe a szolgáltatást, mivel a szombati kézbesítésre is szükségük van.

Az elemzések során megállapították, hogyha a Dán Posta a heti hatszori kézbesítés helyett csak 5 alkalommal kézbesítene, mintegy 130 millió dán koronát (4,7 milliárd Ft-ot) lehetne megtakarítani. Ez az érték már a kézbesítési gyakoriság csökkentésének nettó költségét jelenti, melynek magyarázatát az 5. táblázat foglalja össze. 
Az USO-val együtt járó előnyök-

A Dán Posta tekintetében

azonosított nettó költség mértéke a kézbesítési gyakoriság csökkentése vonatkozásában

\begin{tabular}{|c|c|c|c|}
\hline & $\begin{array}{l}\text { Heti } 5 \mathrm{x} \text {-i kézbesítés } \\
\text { hatásának helye }\end{array}$ & A hatás & $\begin{array}{l}\text { A hatás értéke } \\
\text { (dán korona) }\end{array}$ \\
\hline \multirow{4}{*}{ 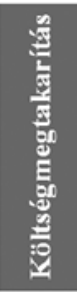 } & Postaládák üritési & Egy napi ürités elmarad & 8 \\
\hline & Útidő & Egy napi útiköltség megtakaritható & 118 \\
\hline & Kiszállás & $\begin{array}{l}\text { Heti egy napi személyes postaszolgáltatás (pl. } \\
\text { felvétel) költsége megtakaritható, de több } \\
\text { költség keletkezik a többi napon }\end{array}$ & 172 \\
\hline & $\begin{array}{l}\text { 6-dik napi } \\
\text { bérköltség }\end{array}$ & Bérköltség c sökkenése & 17 \\
\hline \multirow{2}{*}{ 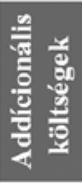 } & $\begin{array}{c}\text { Pénzügyi } \\
\text { szolgáltatások }\end{array}$ & Nagyobb volumen a szolgáltatási napokon & -26 \\
\hline & Extra kiszállási idő & $\begin{array}{c}\text { A magasabb volumen növeli a szolgáltatási } \\
\text { idổt }\end{array}$ & -38 \\
\hline \multirow{5}{*}{ 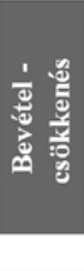 } & Újságok & $\begin{array}{c}\text { Keresletcsökkenés a hétköznapi újságok iránt } \\
\text { a szombati kézbesítés hiányában }\end{array}$ & -64 \\
\hline & $\begin{array}{l}\text { Címzettlen } \\
\text { küldemény }\end{array}$ & Reklámküldemények (?) csökkenése & -13 \\
\hline & Levelek & Levelek számának csökkenése & -39 \\
\hline & Postacsomag & nincs hatással rá & 0 \\
\hline & Összesen & & 133 \\
\hline
\end{tabular}

Forrás: Ballebye Olesen et al., 2008:151. alapján

A már ismertetett, legjelentősebb követelmények mellett vizsgáltak egyéb elvárásokat is, melyeknek a Dán Postának meg kell felelnie.

- A vakok részére nyújtott ingyenes szolgáltatások mintegy 18 millió dán korona (mintegy 650 millió $\mathrm{Ft}$ ) bevételkieséssel járnak.

- Azon termékek vonatkozásában, melyet a Dán Posta a kötelezettségei miatt szolgáltat, megállapítható, hogy nagy valószínúséggel ezeket a kötelezettségek hiányában is nyújtaná. E feltételezés abból adódik, hogy az egyetemes szolgáltató jelenlegi versenytársai a kérdéses termékeket szolgáltatják, így ezek gazdasági alapon történô nyújtása az egyetemes szolgáltatónál is valószínúsíthetô.

- A postahelyekre vonatkozó kötelezettség sem jelenthet többletterhet a Dán Posta számára, mivel a postahelyek számának csökkenése jelentôs csökkenést eredményezne a nyereséges termékek bevételében is.

Az eddig ismertetett elemzések során tehát a Dán Posta vonatkozásában mintegy 4,7 milliárd Ft értékú nettó költség merült fel. Ez az összeg azonban még nem tartalmazza az egyetemes szolgáltatásokkal együtt járó pozitív hatások bevételi oldalát, mely ellensúlyozza a felmerülő költségeket. nél a következó megállapítások tehetốk a Dán Postára.

- A liberalizációt követően feltételezhetô, hogy a Dán Posta, mint egyetemes szolgáltató, a piaci részesedéséból csupán egy csekély részt fog elveszíteni. Ezt a feltételezést a svéd postapiac tapasztalatai alapozzák meg, mivel ott az egyetemes szolgáltató piaci részesedése a nagy menynyiségben feladott levelek terén is eléri a $90 \%$-ot a liberalizáció után 14 évvel.

- Emellett az egyetemes szolgáltató a piacnyitást követóen jelentős piaci előnnyel rendelkezik, mivel az ő tulajdonában van az infrastruktúra. Ennek következtében bevételnövekedésre lehet számítani, tekintve, hogy az új belépók az egyetemes szolgáltató tulajdonában lévő infrastruktúrától függenek.

- Ezen előnyök mellett szükséges egyéb, kizárólag az egyetemes szolgáltatót illetô jogokat is feltérképezni a nettó költség pontosabb meghatározásához. Ilyen lehet például a dán piacon is alkalmazott adóelónyök alkalmazása.

A fent ismertetett előnyök mellett kevésbé számszerúsíthetô elônyök kerültek szóba a Dán Postánál:

- A monopólium ideje alatt kiépített brandnek köszönhetően a fogyasztók előnyben részesítik majd az egyetemes szolgáltatót a versenypiacon is.

- Dániában kizárólag a Dán Posta forgalmazhat „Dánia” feliratú bélyegeket.

- További versenyelőnyt nyújt az egyetemes szolgáltató részére a koronát és kürtöt ábrázoló címer használata, mely a fenti jogok mellett marketingcélokra is használható.

Mivel a marketingköltségek a termékköltség egy jelentős részét képezhetik a postai szolgáltatások esetében, a fent ismertetett marketingelőnyök kihasználása révén jelentôs hasznokkal jár az egyetemes szolgáltatási kötelezettség.

Összességében megállapították, hogy az egyetemes szolgáltatási kötelezettségekból származó költségeket a hasznok fedezik, vagyis a Commercial Approach módszertana alapján nem állapítható meg többletteher. 
A fent ismertetett módszertanok jelentősen eltérnek egymástól, így a köztük való választás jelentôsen befolyásolja a számszerúsített többletteher mértékét.

\section{Az egyetemes szolgáltatási kötelezettségekból adódó többletteher finanszírozása}

nettó költség az egyetemes szolgáltató hatékonyságát, valamint a versenyfeltételeket befolyásolhatja.

$\mathrm{Az}$ Európai Unióban elsôként Svédországban, 1994-ben került sor a postai piacnyitásra. A 6. táblázatban foglaltuk össze, hogy az egyes országokban milyen szinten áll a liberalizáció.

6. táblázat
A III. postai irányelv a többletteher finanszírozását tekintve is megfogalmaz iránymutatásokat, azonban a finanszírozási mechanizmus kialakítását a tagországokra bízza. Az európai uniós iránymutatások a finanszírozáshoz a következók:

A m e n n y ib e n megállapítják, hogy az egyetemes szolgáltatók kötelezettségekból adódó többletterhe „,méltánytalan pénzügyi terhet" jelent, a következô módon kompenzálható az egyetemes szolgáltató:

(1) állami alapokból finanszírozandó a nettó költség, vagy

(2) ki kell alakítani egy olyan finanszírozási mechanizmust, mely a szolgáltatók és/vagy a felhasználók között megosztja ezt a többletterhet $(2008 / 6 / \mathrm{EK}, 7$. cikk [3] bekezdés).

Az irányelv továbbá hangsúlyozza, hogy amennyiben szükséges a nettó költség finanszírozása, úgy azt „objektív, átlátható, megkülönböztetéstól mentes és arányos módon" [...] kell megoldani, hogy ,a lehetó legkisebb torzulást okozza a versenyben és a felhasználók keresletében" (2008/6/EK, 1. melléklet, C rész).

Az egyetemes szolgáltatási kötelezettségekból adódó többletteher minél pontosabb meghatározása tehát nagy jelentőséggel bír, egyrészt azért, mert annak finanszírozását részben vagy egészben az adott ország felhasználóira háríthatja a szabályozó hatóság, másrészt a nem megfelelóen kalkulált

A postapiaci liberalizáció mértéke Európában, 2009, valamint a nettó költség finanszírozása Európábann

A teljes liberalizáció éve A liberalizáció foka Kompenzációs mechanizmus

\begin{tabular}{|c|c|c|}
\hline 1994 & \multirow{4}{*}{ teljes liberalizáció } & nincs \\
\hline 1994 & & $\begin{array}{l}\text { Állami költségvetésböl } \\
\text { finanszírozva 2009-ben* }\end{array}$ \\
\hline 2005 & & nincs \\
\hline 2008 & & nincs \\
\hline- & \multirow{4}{*}{ részleges liberalizáció } & - \\
\hline- & & - \\
\hline- & & - \\
\hline- & & - \\
\hline
\end{tabular}

Több országban még csak részleges piacnyitás történt, ami azt jelenti, hogy egyes szolgáltatásokban már liberalizált a piac. Európa-szerte csak 2009-ben Finnországban került sor kompenzációra a nettó költségek tekintetében. A 3. ábra a 2009-es európai liberalizált piaci viszonyokat ismerteti a liberalizáció tekintetében.

3. ábra

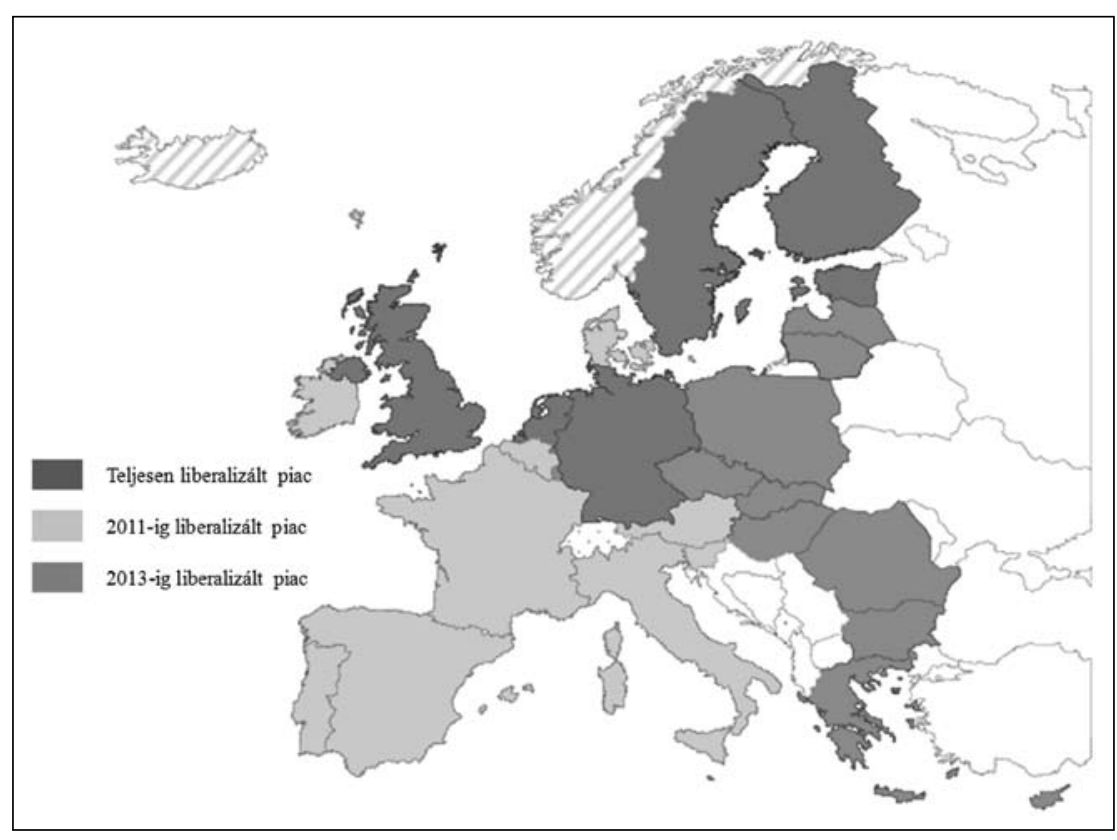

Forrás: WIK Consult - ITA Consulting (2009:20) 
A 3. ábra alapján postapiaci liberalizációban az országok három csoportba sorolhatók: egyes, már említett országokban, mint például Svédország, Egyesült Királyság, már megtörtént a teljes piacnyitás. A második csoportba olyan országok tartoznak, melyek 2011-ig vállalták a postapiac teljes megnyitását, és jellemzően ezen országokban a részleges piacnyitás már megtörtént. Hazánkkal együtt jellemzóen a kelet-európai országok kaptak derogációt 2013-ig a teljes piacnyitásban. Ezen országokban még jelentős piacszabályozási döntések meghozatalára lesz szükség a 2013-as piacnyitásig.

\section{A magyar postapiac liberalizációjára való felkészülés}

2013. január 1-jével a hazai piacot egy, a teljes liberalizációra való felkészülési időszak jellemzi. A hazai postai piacban feltárandó döntési pontokhoz szükséges elóbb feltérképezni az európai liberalizációs tapasztalatokat, melyek a hazai piac megnyitásához alapul szolgálhatnak.

A liberalizáció kapcsán szükséges vizsgálni a piacnyitás utáni piaci viszonyokat, melyek - többek között - hatással lesznek:

- az egyetemes szolgáltató nettó költségének mértékére, valamint

- annak finanszírozására.

Jelenleg a hazai piacon a Magyar Posta Zrt. az egyetemes szolgáltató, mely a következő kötelezettségekkel, valamint jogokkal rendelkezik:

A magyar postapiacon a 2003. évi CI. törvény ismerteti az egyetemes szolgáltatási kötelezettségeket.

E törvény rendelkezései értelmében az egyetemes postai szolgáltatónak a következó kötelességei vannak az egyetemes szolgáltatások tekintetében:

- Az egyetemes postai szolgáltató az egyetemes szolgáltatása keretében nyújtott küldeményeihez köteles ajánlott különszolgáltatást (kivéve postacsomag), tértivevény, valamint értéknyilvánítás különszolgáltatást nyújtani (2003. évi CI. törvény a postáról 5.§ [2] bekezdés).

- Az egyetemes postai szolgáltatás körébe tartozó szolgáltatást, illetve az ahhoz tartozó különszolgáltatásokat az egyetemes postai szolgáltatónak teljes körben, az ország egész területén el kell látnia oly módon, hogy az foglalja magába a postai küldeményeknek munkanaponként legalább egyszeri gyújtését és házhoz kézbesítését (2003. évi CI. törvény a postáról $6 . \$[1]$ bekezdés).

A fent említett kötelezettségek mellett a magyar egyetemes szolgáltatónak kizárólagos jogosultsága van a postakürt jelvénynek és a jelvény stilizált változatának a postatörvény hatályát érintő használatára, valamint a „Magyarország” vagy „Magyar Posta” felirattal, illetve annak idegen nyelvü megfelelőjével rendelkezó bérmentesítésilenyomat használatára, valamint ugyanezen felirattal rendelkezô postai értékcikk kibocsátására és forgalomba hozatalára.

A fent bemutatott előnyök értelmében szükséges megjegyezni, hogy a postabélyeg ${ }^{2}$ kibocsátása kizárólag az egyetemes szolgáltatót illeti meg, ezáltal jelentôs haszon keletkezik a Magyar Postánál. Emellett a liberalizációt követően lehetőség nyílik majd a postahálózathoz való hozzáférésre bármely szolgáltató számára, mely pótlólagos bevételt jelenthet a Magyar Posta számára. Ennek következtében tehát lehetséges, hogy a jelenleg veszteséges postahelyekhez kapcsolódóan a Magyar Postának pótlólagos bevétele képződik a hálózati hozzáférési díjból.

Mindezen kötelezettségeket és jogosultságokat figyelembe véve szükséges meghatározni a Magyar Posta egyetemes szolgáltatásának nettó költségét. Tekintettel arra, hogy a III. irányelv a fenntartott szolgáltatások körét megszünteti, nem egyértelmú a postakürt jelvény, valamint a Magyar Posta felirat használatának jövője. Az ezekból származó lehetséges versenyelőny, valamint bevételtömeg az egyetemes szolgáltatásból eredő haszonnak feleltethetô meg, melynek számszerú figyelembevétele szükséges lehet a nettó költség meghatározása során.

A többletterhek megállapítását követően szükséges kidolgozni egy, a piaci specifikumoknak megfelelő finanszírozási metódust, mely a legkevésbé torzítja a versenyfeltételeket, és emellett átlátható objektív és megkülönböztetéstől mentes.

A fenti döntési pontok tekintetében tehát a szabályozó hatóságnak a 4. ábrán ismertetett döntési fa mentén kell haladnia.

Ezek tehát a legfontosabb teendók, melyek elengedhetetlenek a piacnyitáshoz. E piaci változásokkal párhuzamosan természetesen a jogszabályi környezet módosítása is szükséges, adaptálva ezáltal a III. irányelv rendelkezéseit.

A fent ismertetett feladatok elvégzése érdekében szükséges egy mélyreható postapiaci vizsgálat, melyben feltárják a lehetséges liberalizációs hatásokat mind a keresletre, mind a kínálatra.

\section{Konklúzió}

A tanulmány célja, hogy felhívja a figyelmet a postapiac jelenlegi, nemzetközi szinten nem szabályozott kérdésköreire. A piac liberalizációjának kapujában egyre fontosabb kérdéssé válik, hogy az egyetemes szolgálta- 
A szabályozó hatóságok döntési pontjai

a liberalizáció tekintetében

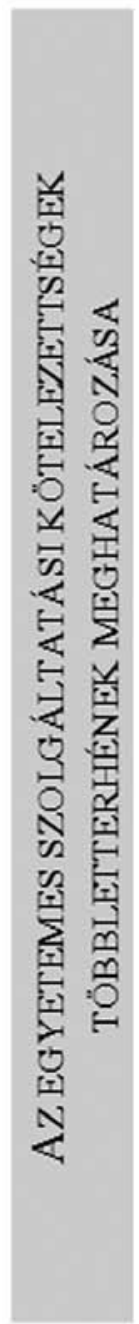

\section{NETTÓKÖLTSÉG MEGHATÁROZÁSÁNAK \\ VONATKOZÓ LEHETÖSÉGEK \\ VIZSGÁLATA}

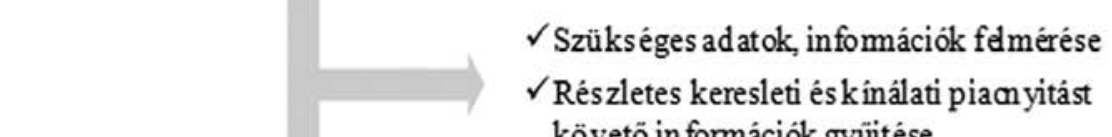
követö in formációk gyüjtése
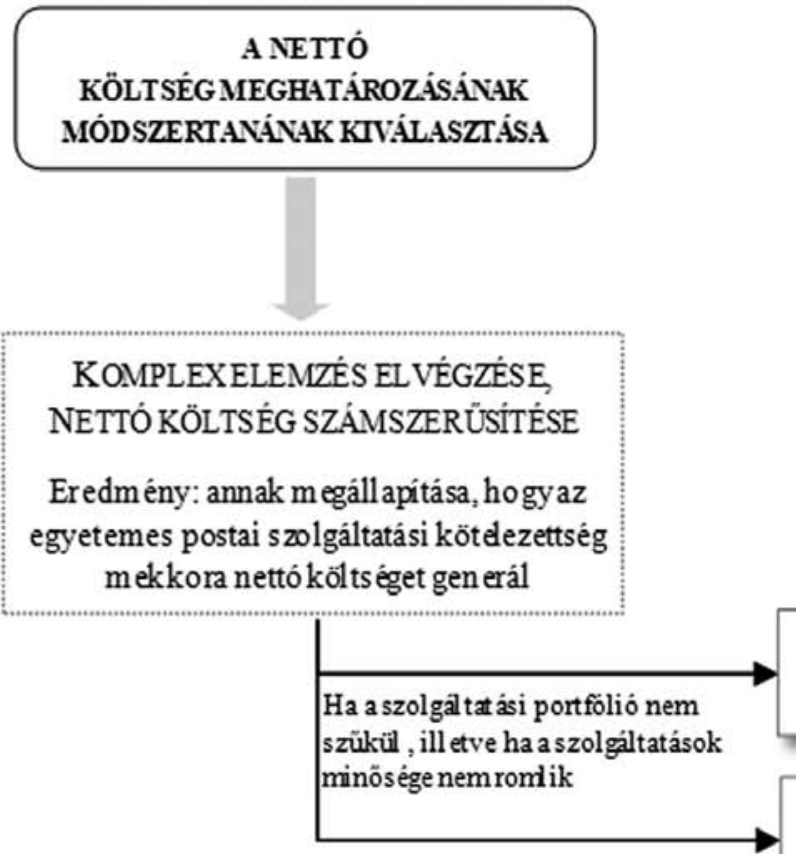

$\mathrm{Ha}$ a szolgaltatások al acs onyabb A KÖTELEZETTSÉGEKNEK NINCS TÖBBLETTERHE

A KÖTELEZETTSÉGEKNEK VAN minösègüek, kevésbé széles körüek ès TÖBBLETTERHE

FINANSZIROZÁSIMECHANIZMUS

LEHETÖSÉGEINEK VIZSGÁLATA
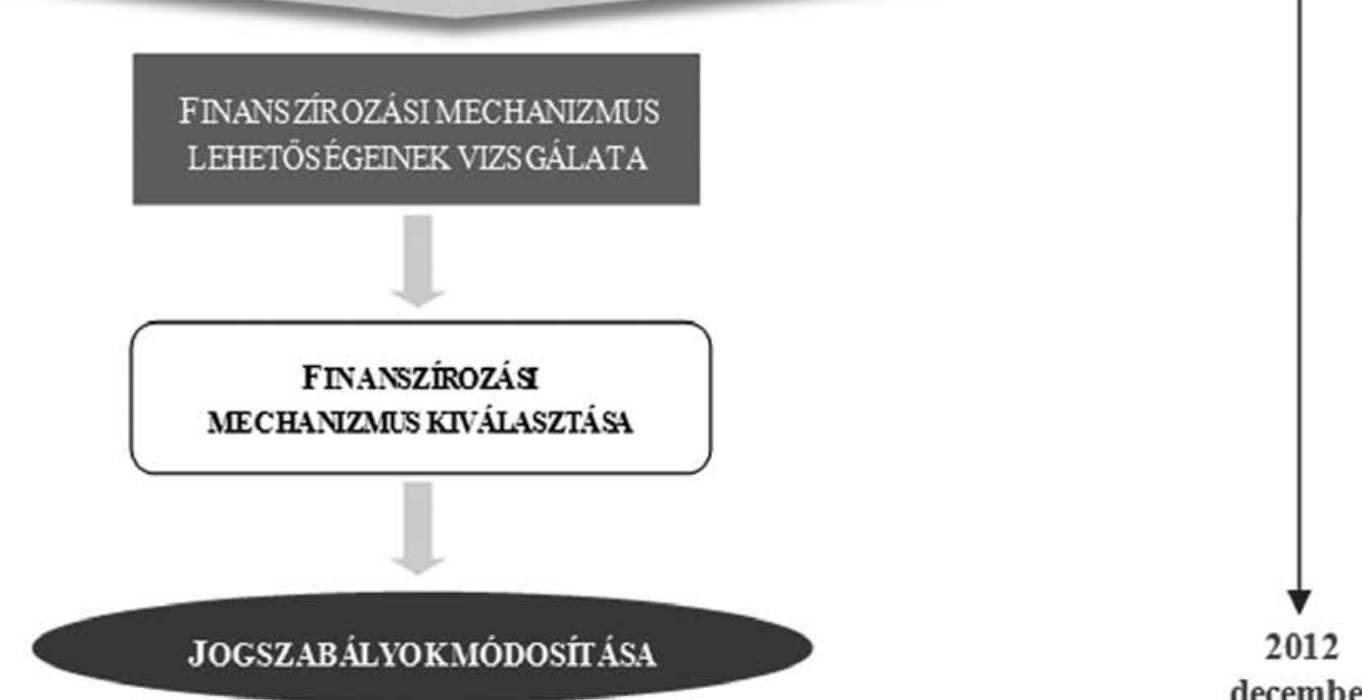

december 
tási kötelezettségek valójában jelentenek-e, és ha igen mekkora többletterhet az egyetemes szolgáltatóknak. A cikkben a nemzetközi viszonylatban leginkább ismert és a gyakorlatban is alkalmazott módszereket mutattuk be, kiemelve azok elónyeit, hátrányait, valamint a legújabb, 2008-as postai irányelvnek való megfelelőségüket. Az egyetemes szolgáltatási kötelezettség többletterhe mellett a másik jelentős kérdéskör a liberalizációban a többletteher finanszírozási mechanizmusának kialakítása. A 2008-as irányelv erre is fogalmaz meg iránymutatásokat, azonban a megfeleló finanszírozási mechanizmus kialakítása jelentôs mértékben függ az adott nemzet postapiaci körülményeitôl, szabályozásától, valamint a megállapított többletteher mértékétól. A jelen kutatási téma aktualitása, hogy Magyarország jelenleg a liberalizációra való felkészuilés idôszakában van, tekintve, hogy hazánk - más országokkal egyetemben - derogációban részesült a teljes piacnyitás vonatkozásában 2013. január 1-jéig. Ennek kapcsán a szerzók bemutatják a jelenlegi magyar piacon múködő egyetemes szolgáltató, a Magyar Posta Zrt. szolgáltatási kötelezettségeit, és kizárólagos jogait, melyek figyelembevételével szükséges megállapítani a többletterhek mértékét.

További kutatási téma alapja lehet az elkövetkezó közel hároméves felkészülési idôszak a hazai piac vonatkozásában, mely idő alatt egy átfogó piacszabályozás kialakítása szükséges. A hazai postapiac stratégiájának kialakítása keretében az árszabályozás mellett szükséges - többek között - a szabályozói hatáskörök meghatározása, valamint a hálózathoz való hozzáférés szabályozásának kialakítása. E feladatok elvégzése még várat magára, ezáltal az illetékes hatóságok rendelkezésére álló idő a megfelelő szabályozási keretek kialakítására egyre rövidebb, mely a sikeres 2013-as piacnyitást veszélyeztetheti.

\section{Lábjegyzet}

${ }^{1}$ Magyarországon az I. postai irányelv életbe lépésétól kezdve a fenntartott szolgáltatási kör a lehetô legszélesebb körú szolgáltatásokat foglalta magában.

2 A 2003. évi CI. törvény 3. $\$ 16$. pontja értelmében a postabélyeg „az egyetemes postai szolgáltató által kibocsátott, a postai küldemények bérmentesítési dijának lerovására használható postai értékcikk” [...]

\section{Felhasznált irodalom}

A 2002/39/EK Irányelv, a 97/67/EK Irányelvnek a közösségi postai szolgáltatások verseny számára való további megnyitása tekintetében történô módosításáról

A 2008/6/EK Irányelv, a 97/67/EK Irányelvnek a közösségi postai szolgáltatások belsô piacának teljes megvalósítása tekintetében történố módosításáról

A 97/67/EK Irányelv a közösségi postai szolgáltatások belsô piacának fejlesztésére és a szolgáltatás minőségének javítására vonatkozó közös szabályokról

2003. évi CI. törvény a postáról

Ballebye Olesen et al. (2008): What is the cost of Post Danmark's universal service obligation?; Copenhagen Economics

Crew, M.A. - Kleindorfer, P.R. (2008): Competition and Regulation in the Postal and Delivery Sector; Edward Elgar

Crew, M.A. - Kleindorfer, P.R. - Campbell, J.I. (2008): Handbook of Worldwide Postal Reform; Edward Elgar

WIK Consult (2009): The Role of Regulators in a More Competitive Postal Market

WIK Consult - ITA Consulting (2009): The Evolution of the European Postal Market since 1997 